\title{
Stabilization of Slug by NF-kB is Essential for TNF- $\alpha$-Induced Migration and Epithelial-Mesenchymal Transition in Head and Neck Squamous Cell Carcinoma Cells
}

\author{
Shuli Liu ${ }^{a, b, c}$ Lei Shid Yang Wanga,b,c Dongxia Ye ${ }^{a, b, c}$ Houyu Ju $u^{a, b, c}$ \\ Hailong Ma $a^{a, b, c}$ Wenyi Yang ${ }^{a, b, c}$ Yanan Wang ${ }^{a, b, c}$ Jingzhou $\mathrm{Hu}^{\mathrm{a}, \mathrm{b}, \mathrm{c}}$ \\ Jiong Deng ${ }^{e, f, g}$ Zhiyuan Zhang ${ }^{a, b, c}$
}

\begin{abstract}
aDepartment of Oral and Maxillofacial-Head and Neck Oncology, Ninth People's Hospital, Shanghai Jiao Tong University School of Medicine, Shanghai, ${ }^{b}$ Shanghai Key Laboratory of Stomatology \& Shanghai Research Institute of Stomatology, Shanghai, 'National Clinical Research Center of Stomatology, Shanghai, 'Department of Oral and Maxillofacial Surgery, Gansu Provincial Hospital, Gansu, eKey Laboratory of Cell Differentiation and Apoptosis of Chinese Minister of Education,

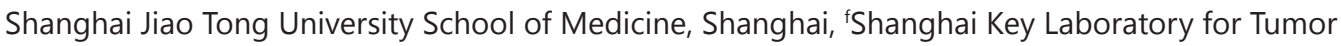
Microenvironment and Inflammation, Shanghai Jiao Tong University School of Medicine, Shanghai, 9Translation Medicine Center, Shanghai Chest Hospital, Shanghai Jiao Tong University, Shanghai, China
\end{abstract}

\section{Key Words}

TNF- $\alpha \cdot$ Slug $\cdot$ HNSCC $・$ EMT $・ N F-K B$

\begin{abstract}
Background/Aims: Slug protein, a transcription factor for the induction of epithelialmesenchymal transition (EMT) and cancer cell invasion and metastasis, is frequently upregulated in human epithelial cancers. However, mutation of this gene in cancer is rare, and the mechanism of its dysregulation remains unknown, especially in head and neck squamous cell carcinoma (HNSCC). Methods: We examined the role of TNF- $\alpha$ in the stabilization of Slug by immunoprecipitation-westernblot analysis. Migration of HNSCC cells with or without knockdown of Slug gene expression was assayed by a wound healing assay. Immunohistochemical staining analysis was used to measurement Slug levels in both normal and HNSCC tumor tissues. Results: The inflammatory cytokine TNF- $\alpha$ stabilized Slug protein by inhibiting its ubiquitination through the NF-kB pathway. Inhibition of NF-kB or knockdown of p65 abrogated the TNF- $\alpha$-induced stabilization of Slug. Knockdown of Slug expression inhibited cancer cell migration and EMT characteristics induced by TNF- $\alpha$. Moreover, increased levels of Slug were found to correlate with lymph node metastasis and predict poor prognosis in patients with HNSCC. Conclusions: NF-KB-mediated stabilization of Slug underlies the inflammation-induced EMT and metastasis in HNSCC, which may serve as a therapeutic target for metastatic HNSCC.

S. Liu, L- Shi and Y. Wang contributed equally to this work.




\section{Introduction}

Approximately $90 \%$ of cancer deaths are caused by metastasis, yet it remains the most poorly understood component of cancer pathogenesis because of its complexity [1]. Emerging evidence suggests that epithelial-mesenchymal transition (EMT), which is an essential phenotypic conversion during embryonic development, tissue remodeling, and wound healing, plays an important role in cancer metastasis [2-4]. During EMT, epithelial cells acquire fibroblast-like properties, exhibit reduced intercellular adhesion, and show increased motility. Several transcription factors are key regulators of EMT, including the Snail/Slug family, Twist, $\delta$ EF1/ZEB1 and SIP1/ZEB2 [5-12].

Slug is known to promote tumor progression and metastasis through EMT, causing loss of cell adhesion and polarity while conferring migratory and invasive properties [13, 14]. Consistent with its vital role in cancer metastasis, an overabundance of Slug protein is observed in many types of cancer, including head and neck squamous cell carcinoma (HNSCC) $[15,16]$. However, despite its frequent overabundance, Slug is rarely mutated or amplified in HNSCC. Slug is a labile protein that is degraded rapidly in normal tissue. Interestingly, increased Slug stability has been observed in cancer cells, which is linked to the repression of proteasomal degradation [16]. However, the mechanism by which Slug escapes proteasomal degradation in cancer cells remains unknown. Thus, elucidating the molecular mechanism underlying the phenomenon of increased Slug stability may provide a new target for cancer therapeutic intervention.

The processes involved in the invasive growth and metastasis of tumors are complex and vary depending not only on the intrinsic characteristics of the tumor cells themselves but also on the microenvironments where tumors originate. Tumor promotion by the microenvironment is largely orchestrated by inflammatory cells that facilitate extracellular matrix breakdown, angiogenesis, and tissue remodeling, thus promoting the motility of tumor cells $[17,18]$. The complex interactions between a tumor and inflammatory cells mediated by inflammatory cytokines are an essential aspect of the tumor microenvironment. The association of inflammation and cancer has been well recognized in many types of cancer, and inflammation is regarded as the "seventh hallmark of cancer" [19, 20]. Accumulating evidence has shown that TNF- $\alpha$ is a key mediator of inflammation and cancer $[21,22]$. Increased TNF- $\alpha$ expression and serum TNF- $\alpha$ levels are associated with clinical cancer stages, high-grade malignancies, and poor prognosis in HNSCC and several other cancers [23, 24]. However, the comprehensive mechanism by which TNF- $\alpha$ promotes HNSCC metastasis remains unclear.

In this study, we investigated the roles of TNF- $\alpha$ in the metastatic features of HNSCC. We found that stabilized Slug is essential for TNF- $\alpha$-induced migration and EMT characteristics in HNSCC. Importantly, NF- $\kappa B$ mediates the effect of TNF- $\alpha$ on the stabilization of Slug protein by inhibiting its ubiquitination-mediated degradation. Moreover, Slug overexpression was found to correlate with lymph node metastasis and poor prognosis in HNSCC. Thus, the TNF$\alpha$-NF- $\kappa B-S l u g$ axis represents a therapeutic target for metastatic HNSCC.

\section{Materials and Methods}

Cell cultures and reagents

HNSCC-derived cell lines HN4, HN12, HN13 was kindly provided by the University of Maryland, School of Dentistry. CAL27 cell line was purchased from the American Type Culture Collection (ATCC). Cells were cultured in Dulbecco's modified Eagle's medium (DMEM; Gibco) supplemented with $10 \%$ fetal bovine serum, $1 \%$ glutamine, and $1 \%$ penicillin-streptomycin. All cells were maintained in a humidified atmosphere of $5 \% \mathrm{CO}_{2}$ at $37^{\circ} \mathrm{C}$. Antibodies for Slug (\#9585), GAPDH (\#9585), p65(\#8242), E-cadherin (\#3195), N-cadherin (\#13116), Vimentin (\#5741), Oct4 (\#2750), Sox2 (\#3579), GSK3 B (\#12456) were from Cell 


\section{Cellular Physiology Cell Physiol Biochem 2018;47:567-578 \begin{tabular}{l|l} 
and Biochemistry Published online: $\mathrm{xxx}, 2018$ & $\begin{array}{l}\text { ( ) 2018 The Author(s). Published by S. Karger AG, Basel } \\
\text { www.karger.com/cpb }\end{array}$
\end{tabular}}

Liu et al.: TNF- $\alpha$ Stabilizes Slug via NF-KB in HNSCC

Signaling Technology Inc. HRP-conjugated secondary antibodies were from eBioScience (San Diego, CA). Human recommend TNF- a was obtained from R\&D system (Minneapolis, MN, USA).

\section{Immunoprecipitation and Western Blotting}

Experiment protocol was performed as described previously $[25,26]$. Cells were lysed with RIPA lysis buffer. Immunoprecipitation was performed with 2 ug of antibody against Slug, Ubiquitin or normal IgG (as a negative control) in 1.0-mg whole-cell lysate. Cell lysates and/or immunoprecipitation cellular proteins were separated by SDS-PAGE in a 10\% acrylamide gel and transferred onto nitrocellulose membrane for immunoblot.

\section{Reverse Transcriptase Polymerase Chain Reaction (RT-PCR)}

Experiment protocol was performed as described previously $[27,28]$. Total RNA samples were extracted with TriPure Isolation Reagent (Roche, Switzerland) and cDNA prepared from $1 \mathrm{mg}$ of total RNA using the SuperScript III System (Invitrogen Life Technologies). The mRNAs levels were determined by RT-PCR, using the following primers: Slug (F: 5'-GAGCATTTGCAGACAGGTCA-3' and R: 5'-CCTCATGTTTGTGCAGGAGA-3'); GAPDH (F:5'-TCCACCACCCTGTTGCTGTA-3' and R: 5'-ACCACAGTCCATGCCATCAC-3').

\section{Wound healing assay}

Experiment protocol was performed as described previously [29, 30]. Cells were plated to confluence in a 6-well plate, and the cell surface was scratched using a pipette tip. Accurate wounds measurements were taken at 0 and 24 hours to calculate the migration rate according to the equation. Three independent experiments were carried out.

\section{Primary HNSCC samples}

All of the methods were approved by the research medical ethics committee of Shanghai Jiao Tong University and were performed in accordance with the approved guidelines. We obtained archival, formalin-fixed and paraffin-embedded (FFPE) material from surgically resected HNSCC specimens from Ninth People's Hospital (Shanghai, CHINA), from 2007 to 2011. In total, 85 primary HNSCC patients without prior radiotherapy or chemotherapy were enrolled in this study. The age of these patients ranged from 18 to 83 years with an average 57.0 years. Histopathologic diagnosis of each neoplastic tissue was performed according to the World Health Organization criteria by the Department of Oral Pathology, Ninth People's Hospital of Shanghai. Clinicopathologic staging was determined by the TNM classification of the International Union against Cancer. This study was approved by the Ethics Committee of Shanghai Ninth People's Hospital, Shanghai Jiao Tong University School of Medicine and carried out according to the recommendations of the Declaration of Helsinki. All the patients involved in this study signed written informed consent in accordance with the institutional guidelines.

\section{Immunohistochemistry}

Immunohistochemistry was performed as previously described [31]. Immunohistochemical staining was performed on the sections (3- $\mu$ m thickness) of paraffin-embedded specimens. Briefly, the sections were dewaxed in xylene and hydrated with graded ethanol. Then antigen retrieval was carried out using $0.01 \mathrm{mM}$ citrate buffer ( $\mathrm{pH}$ 6.0) pressure-cooking, and endogenous peroxidase activity was blocked with $3 \%$ hydrogen peroxide for 10 minutes at room temperature. The slides were incubated with anti-Slug in a moist chamber for overnight at $4^{\circ} \mathrm{C}$. Upon incubation with the primary antibody, the specimens were washed three times in PBS and visualized using 3, 3'-diaminobenzidine detection kit (Dako Cytomation, Denmark). Samples were then counterstained with hematoxylin, a blue nuclear stain. Tumor cells were considered Slug-positive if the immunoreactivity was observed in the nucleus and/or cytoplasm. The mean percentage of positive tumor cells was determined at least five random fields at $\times 400$ magnification in each section. The percentage of positive tumor cells was assigned to one of the following categories: $0,<5 \%$; 1 , $5-25 \% ; 2,26-50 \% ; 3,51-75 \%$; and $4,>75 \%$. The intensity of Slug immunostaining was scored as follows: (a) weak, 1+; (b) moderate, 2+; and (c) intense, 3+. The percentage of positive tumor cells and the staining intensity were multiplied to produce a weighted score for each case. Cases with a weighted Slug score $\geqq 2$ were considered to be positive. These judgments were made by two independent pathologists, neither of whom had knowledge or information pertaining to the patients' clinical status. 


\section{Cellular Physiology Cell Physiol Biochem 2018;47:567-578 \begin{tabular}{l|l} 
and Biochemistry Published online: $x \times x, 2018$ & $\begin{array}{l}\text { D) } 2018 \text { The Author(s). Published by S. Karger AG, Basel } \\
\text { www.karger.com/cpb }\end{array}$ \\
\hline
\end{tabular}}

Liu et al.: TNF- $\alpha$ Stabilizes Slug via NF-KB in HNSCC

Statistical analysis

Data analysis used SPSS (Statistic Package for Social Sciences) 13.0 for Windows (SPSS Inc., Chicago, IL, USA). Unpaired Student's t-tests or U-Mann Whitney tests determined statistical significance between groups with $\mathrm{P}$ values $<0.05$ considered significant.

\section{Results}

TNF- $\alpha$ induces Slug protein stabilization

To identify the factors that are important for the regulation of Slug, we established a HEK293F-Slug stable transfectant cell line and examined various pro-inflammatory cytokines for their ability to stabilize Slug. Strikingly, we found that TNF- $\alpha$ was the most potent cytokine for the stabilization of Slug (data not shown). To further validate this observation, we also examined the effects of TNF- $\alpha$ on two HNSCC cancer cell lines (CAL27 and HN13). TNF- $\alpha$ treatment increased the level of Slug protein in both cell lines (Fig. 1A). Interestingly, the mRNA level of Slug did not show a significant elevation with TNF- $\alpha$ treatment as measured by RT-PCR (Fig. 1B). These results suggest that the TNF- $\alpha$-induced elevation of Slug is likely through protein stabilization. Next, we examined the kinetic features of Slug following TNF- $\alpha$ treatment. TNF- $\alpha$ treatment increased Slug level within $1 \mathrm{~h}$ and reached a maximum level at approximately $4 \mathrm{hr}$ without significant mRNA elevation (Fig. 1C and 1D). These results strongly demonstrate that the pro-inflammatory cytokine TNF- $\alpha$ increases Slug in HNSCC cells in a transcription-independent manner.

TNF- $\alpha$ enhances Slug stability by inhibiting its ubiquitination

Slug is a labile protein. To determine the regulatory mechanism underlying the TNF$\alpha$-induced stabilization of Slug we examined the protein levels of Slug in cells treated with

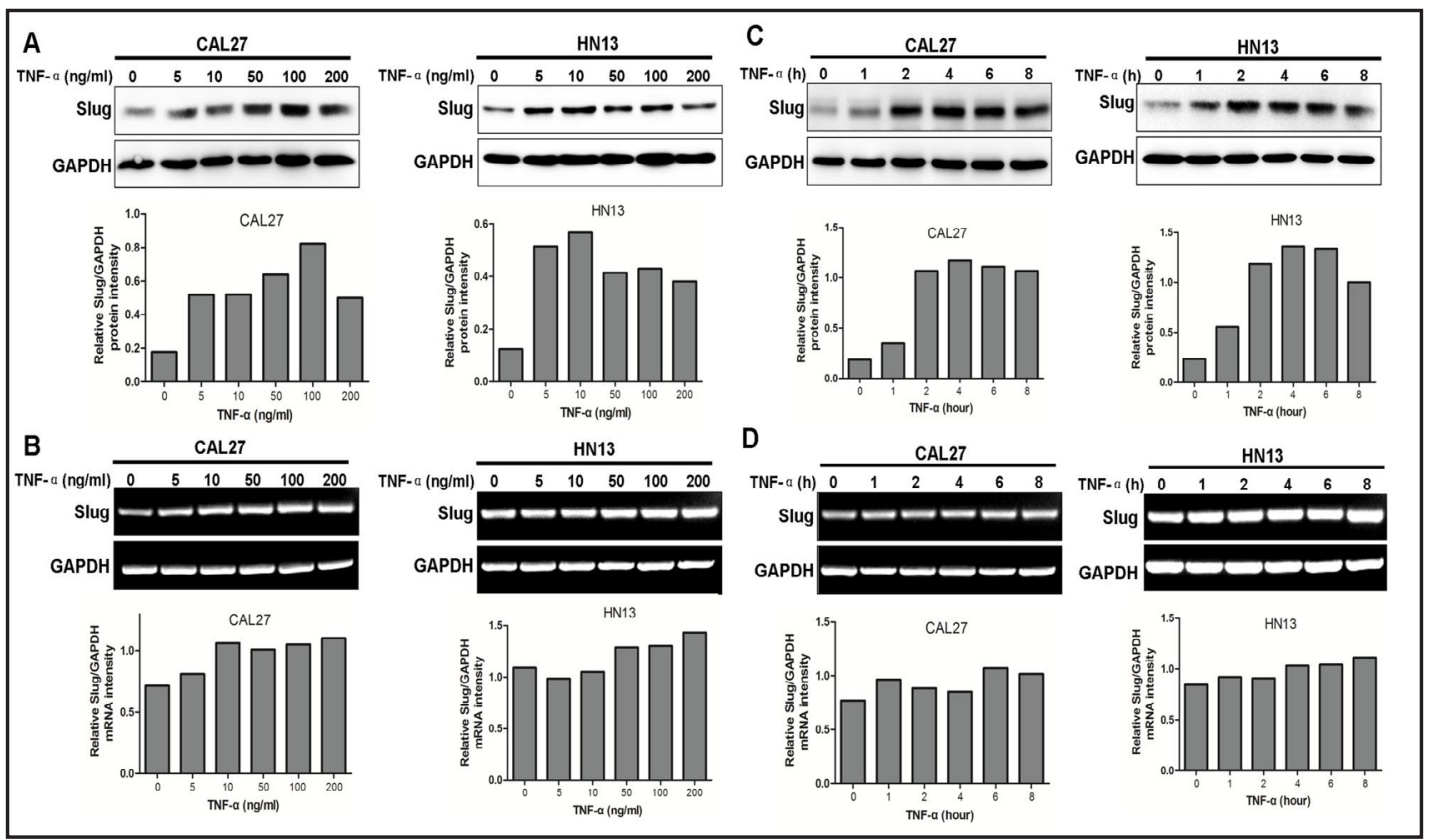

Fig. 1. TNF- $\alpha$ induces the stabilization of Slug protein. (A) Western blot analyses of Slug in CAL27 and HN13 cells treated with 0-200 ng/mL TNF- $\alpha$ for $4 \mathrm{~h}$ (upper panel) and the relative expression of Slug protein for each sample after normalization to GAPDH (lower panel). (B) RT-PCR analyses of Slug mRNA levels in CAL27 and HN13 cells treated with $0-200 \mathrm{ng} / \mathrm{mL}$ TNF- $\alpha$ for $4 \mathrm{~h}$. (C) Slug protein in CAL27 and HN13 cells treated with TNF- $\alpha$ (100 ng/mL) for different time intervals was analyzed by western blotting. (D) RT-PCR analyses of Slug mRNA levels in cells treated with TNF- $\alpha(100 \mathrm{ng} / \mathrm{mL})$ for different time intervals. 
or without TNF- $\alpha$ for different lengths of time (up to $4 \mathrm{~h}$ ) in the absence or presence of the protein translation inhibitor cycloheximide (Fig. 2A and 2B). TNF- $\alpha$ treatment significantly slowed down the rate of Slug degradation (Fig. 2C). This observation was confirmed further via immunofluorescence microscopy, in which the staining intensity of Slug was dramatically increased in CAL27 and HN13 cells treated with TNF- $\alpha$ (Fig. 2D and 2E). Taken together, these results suggest that TNF- $\alpha$ treatment induces the stabilization of Slug.

As the stabilization of Slug by TNF- $\alpha$ occurs at the protein level, we next asked whether TNF- $\alpha$-induced Slug stabilization is through regulation of the ubiquitination pathway. We examined Slug levels in several HNSCC cells lines treated with or without the proteasome inhibitor MG132, and found that Slug was stabilized by MG132 treatment (Fig. 3A). To determine whether Slug was regulated through ubiquitination, we performed immunoprecipitation-westernblot analysis and found that ubiquitylation of FLAG-tagged Slug was significantly reduced in TNF- $\alpha$ treated cells compared with untreated cells (Fig. 3B). Similarly, TNF- $\alpha$ treatment also dramatically suppressed the ubiquitylationn of endogenous Slug compared to with that on untreated cells (Fig. 3C). Taken together, these results demonstrated that the stabilization of Slug by TNF- $\alpha$ was mediated by the suppression of its ubiquitylation.

Fig. 2. TNF- $\alpha$ enhances the stability of Slug. (A) CAL27 cells were treated with or without TNF- $\alpha(100 \mathrm{ng} / \mathrm{mL})$ for $4 \mathrm{~h}$, followed by incubation with cycloheximide (CHX; $10 \mu \mathrm{M}$ ) for an extended period of time. Slug levels were determined by western blot analysis. (B) HN13 cells were treated with or without TNF- $\alpha$ (100 ng/mL) for $4 \mathrm{~h}$, followed by incubation with CHX $(10 \mu \mathrm{M})$ for an extended period of time. Slug levels were determined by

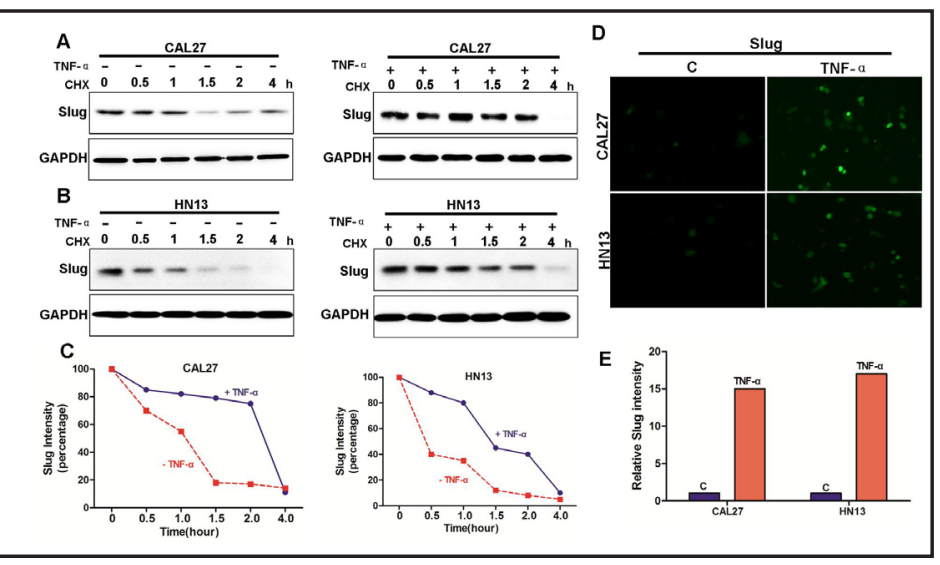
western blot analysis. (C) Graphic representation of the densitometry results for Slug after CHX treatment (circle, with TNF- $\alpha$; square, without TNF- $\alpha$ ). (D) Immunofluorescence staining for Slug in CAL27 and HN13 cells treated with or without 100 ng/mL TNF- $\alpha$ for 4 h. (E) Graphic representation of relative immunofluorescence staining intensity for Slug after treatment with or without $100 \mathrm{ng} / \mathrm{mL} \mathrm{TNF}-\alpha$ for $4 \mathrm{~h}$.

Fig. 3. TNF- $\alpha$ inhibits the ubiquitination of Slug. (A) HEK293-Slug stable cells and HNSCC CAL27, HN12, and HN13 cells were treated with MG132 (10 mM) for $4 \mathrm{~h}$, and Slug was examined by western blotting. (B) HA-ubiquitin was expressed in HEK293-Slug cells followed by treatment with either TNF- $\alpha$ (100 $\mathrm{ng} / \mathrm{mL}$ ) or MG132 (10 mM) for $4 \mathrm{~h}$. Ubiquitin was immunoprecipitated from an equal amount of lysates, and ubiquitinated Slug was examined by western blotting. (C) CAL27 cells were treated with TNF- $\alpha$ (100 ng/mL) or MG132 (10 mM). Endogenous Slug was immunoprecipitated, and the bound endogenous ubiquitin was detected by western blotting.

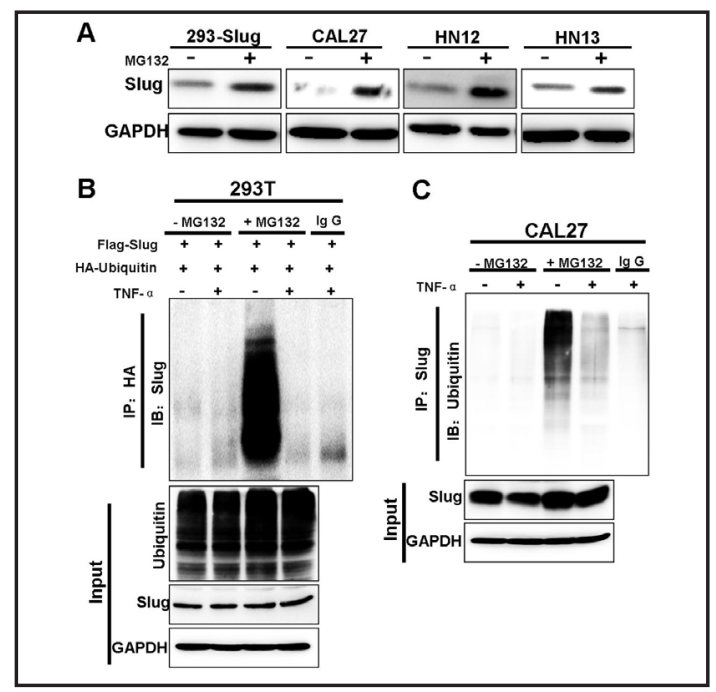




\section{TNF- $\alpha$-mediated Slug stabilization is dependent on NF- $\kappa B$ activation}

To determine which signal transduction pathway is crucial for TNF- $\alpha$-mediated Slug stabilization, we next examined the effects of inhibitors of various signaling pathways including NF- $\kappa$ B, MAPK/ERK, mTOR, p38, and JNK kinases. Only NF- $\kappa$ B inhibitors (BAY11-7082 and BMS-345541) completely blocked TNF- $\alpha$-induced Slug stabilization (Fig. 4A), whereas the effects of the other inhibitors were minimal (data not shown). These results suggest that the NF- $\kappa$ B pathway is crucial for TNF- $\alpha$-mediated Slug stabilization. For further characterization, we examined the effects of overexpressing exogenous p65 in CAL27 and HN13 cells followed by TNF- $\alpha$ treatment. The expression of $\mathrm{p} 65$ dramatically increased Slug protein in these cells (Fig. 4B). Collectively, these results indicate that NF- $\kappa \mathrm{B}$ is crucial for the stabilization of Slug. To determine whether NF- $\kappa \mathrm{B}$ is required for Slug stabilization, we examined the levels of Slug in CAL27 and HN13 cells in which p65 was knocked down by small interfering RNA (siRNA). Knockdown of p65 expression dramatically suppressed the TNF- $\alpha$-induced stabilization of Slug (Fig. 4C). Thus, NF- $\kappa B$ is required for the TNF- $\alpha$-induced stabilization of Slug. To analyze the molecular mechanism for Slug stabilization by p65, we coexpressed p65 with Slug in HEK293 cells. Interestingly, there was no physical association between Slug and

Fig. 4. Activation of the NF- $\kappa B$ pathway is required for the stabilization of Slug. (A) CAL27 and HN13 cells were pretreated with NF- $\kappa$ B inhibitors $(10 \mu \mathrm{M}$ BMS-345541 and $50 \mu \mathrm{M}$ BAY11-7082) for $1 \mathrm{~h}$ followed by stimulation with TNF- $\alpha(100 \mathrm{ng} / \mathrm{mL})$ for $4 \mathrm{~h}$. Slug protein was examined by western blotting. (B) Myc-tagged p65 was expressed in CAL27 and HN13 cells that were treated with or without TNF- $\alpha$ (100 ng/mL) for $4 \mathrm{~h}$. Expression of Slug and p65 was analyzed by western blotting. (C) Control or p65 siRNA was expressed in CAL27 and HN13 cells followed by TNF- $\alpha(100 \mathrm{ng} / \mathrm{mL})$ or vehicle treatment for $4 \mathrm{~h}$. Slug and p65 levels were examined by western blotting.

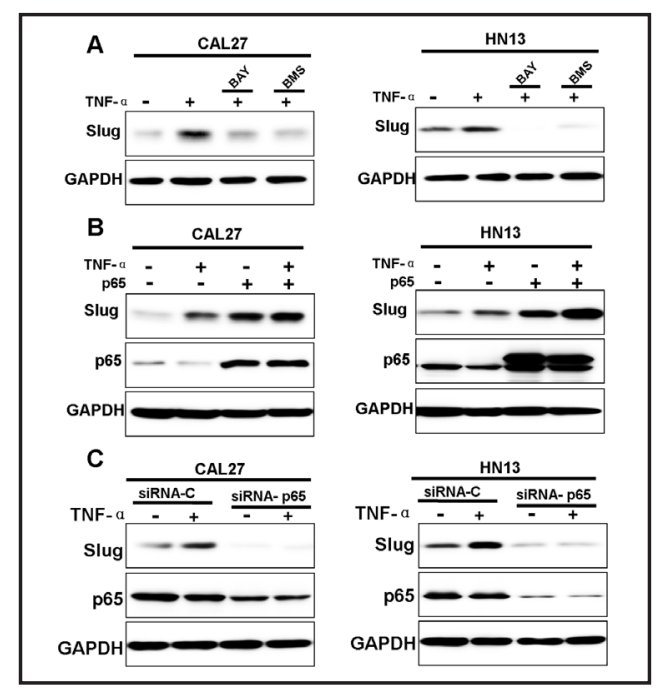

Fig. 5. Knockdown of Slug expression suppresses TNF- $\alpha$ induced cell migration in vitro. (A) The motile behavior of CAL27 and HN13 cells and in their corresponding Slug knockdown cells that were treated with or without TNF- $\alpha$ (100 ng/mL) was analyzed by a wound healing assay. (B) The percentage of migrating cells is shown (mean \pm standard error of the mean in 3 separate experiments). (C) Expression of Slug (treated with TNF- $\alpha$ ), E-cadherin, N-cadherin, and GAPDH in CAL27 and HN13 cells and their corresponding

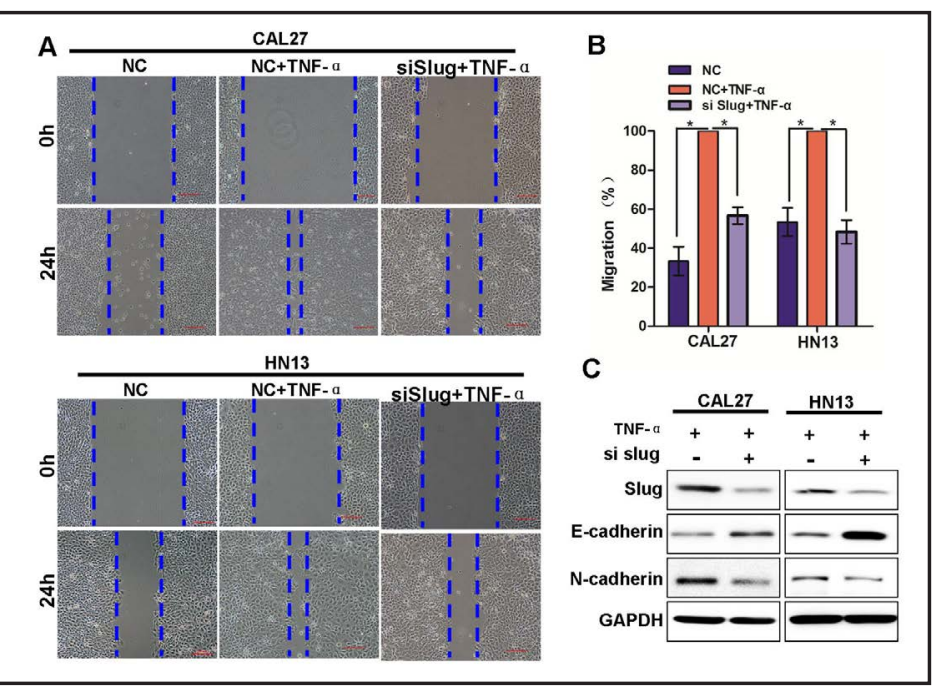
transfectants with knockdown of Slug expression was analyzed by western blotting. 
p65 (data not shown), suggesting that a mediator may be involved in the stabilization of Slug and that this potential mediator is induced by TNF- $\alpha$ or $\mathrm{p} 65$.

Slug is required for TNF- $\alpha$-mediated cell migration in HNSCC

Next, we asked whether Slug is required for the TNF- $\alpha$-induced migration of HNSCC cells. We examined the effects of TNF- $\alpha$ on the migration of HNSCC cells that were treated with or without siRNA-Slug. TNF- $\alpha$ treatment significantly increased cell migration in a wound healing assay. However, this effect was significantly suppressed when Slug was knocked down in both CAL27 and HN13 cell lines (Fig. 5A and 5B). Consistent with the biological changes, the level of Slug altered the expression pattern of EMT markers, in which E-cadherin expression was increased whereas $\mathrm{N}$-cadherin expression was decreased following knockdown of Slug (Fig. 5C). Taken together, these results demonstrated that Slug is required for cell migration mediated by inflammation in HNSCC.

High Slug expression correlates with lymph node metastasis and predicts poor prognosis in patients with HNSCC

Lymph node metastasis is associated with a poor clinical outcome in HNSCC patients and it contains many features that are characteristic of EMT. To determine if Slug plays an important role in lymph node metastasis in HNSCC, we examined Slug protein levels in 85 paired normal and primary HNSCC samples by immunohistochemistry (IHC) staining analysis. A summary of patient demographics and clinicopathological data is shown in Table 1. IHC staining analysis demonstrated that normal tissues had low Slug protein expression. In contrast, Slug protein was expressed at a high level in HNSCC tissues (Fig. 6A and 6B). Of note, Slug protein expression (IHC score) was significantly higher in patients with lymph node metastases (M-tumor) than in patients without lymph node metastasis (NM-tumor) (Fig. 6A and 6B). Taken together, the results of IHC staining analysis showed that Slug upregulation was strongly associated with lymph node

Table 1. The baseline characteristics of HNSCC patients include in the study

\begin{tabular}{|c|c|c|}
\hline \multirow[t]{2}{*}{ Characteristics } & \multicolumn{2}{|c|}{ Patients } \\
\hline & No. & $\%$ \\
\hline \multicolumn{3}{|l|}{ Age, years } \\
\hline$\leq 60$ & 53 & 62.3 \\
\hline$>60$ & 32 & 37.7 \\
\hline \multicolumn{3}{|l|}{ Sex } \\
\hline Male & 45 & 52.9 \\
\hline Female & 40 & 47.1 \\
\hline \multicolumn{3}{|l|}{ T-primary tumor size } \\
\hline $\mathrm{T} 1$ & 24 & 28.2 \\
\hline $\mathrm{T} 2$ & 35 & 41.2 \\
\hline $\mathrm{T} 3$ & 14 & 16.5 \\
\hline $\mathrm{T} 4$ & 12 & 14.1 \\
\hline \multicolumn{3}{|c|}{$\mathrm{N}$-regional lymph node } \\
\hline Negative & 55 & 64.7 \\
\hline Postive & 30 & 35.3 \\
\hline \multicolumn{3}{|l|}{ TNM stage } \\
\hline I & 25 & 29.4 \\
\hline II & 23 & 27.1 \\
\hline III & 20 & 23.5 \\
\hline IV & 17 & 20.0 \\
\hline \multicolumn{3}{|c|}{ Histopathological type } \\
\hline Grade 1 & 36 & 42.3 \\
\hline Grade 2 & 40 & 47.1 \\
\hline Grade 3 & 9 & 10.6 \\
\hline \multicolumn{3}{|l|}{ Smoking history } \\
\hline Yes & 29 & 34.1 \\
\hline No & 56 & 65.9 \\
\hline \multicolumn{3}{|l|}{ Alcohol history } \\
\hline Yes & 22 & 25.9 \\
\hline No & 63 & 74.1 \\
\hline Total & 85 & 100 \\
\hline
\end{tabular}


Fig. 6. High Slug expression is associated with lymph node metastasis and predicts poor prognosis in patients with HNSCC. (A) Normal and tumor samples from HNSCC patients without lymph node metastasis showed low Slug expression, whereas tumor samples from HNSCC patients with lymph node metastasis showed high Slug expression. Bar $=500 \mu \mathrm{m}$. (B) $\mathrm{IHC}$ scores of Slug expression in normal and HNSCC samples with or without metastasis. Statistically significant differences were detected using measures analysis of the Wilcoxon signed-rank test

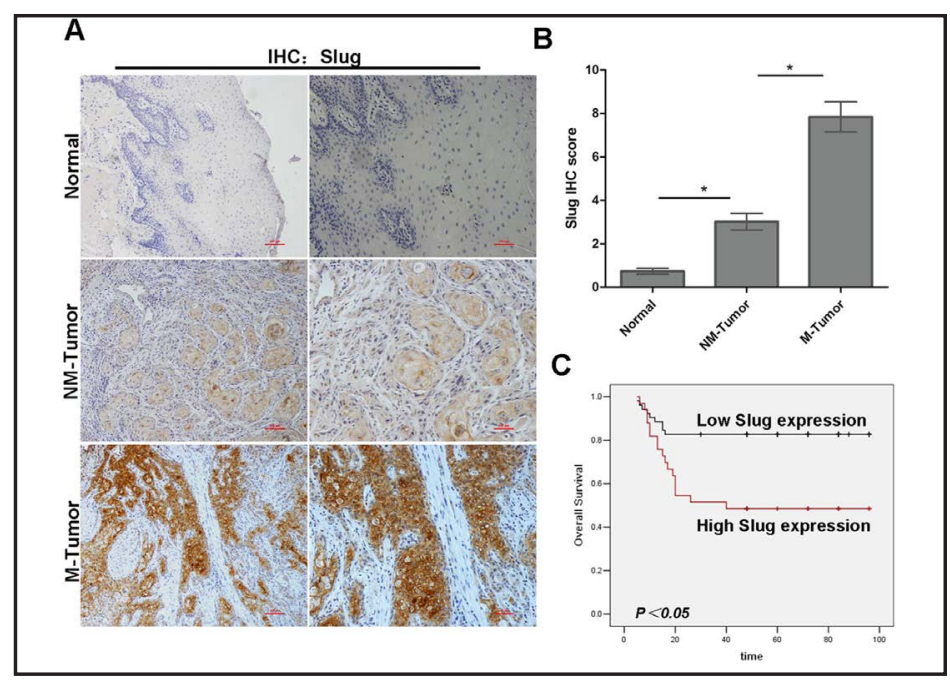
$(\mathrm{P}<0.001)$. (C) High Slug expression was significantly correlated with a poor survival rate of HNSCC patients. The survival rates of patients with Slug-positive and Slug-negative tumors $(\mathrm{P}<0.05)$ were calculated using the Kaplan-Meier survival test.

metastasis in HNSCC patients. As regional lymph node metastasis is considered a major risk factor for poor survival in patients with HNSCC, we investigated the relationship between Slug expression and survival rate of HNSCC patients. By performing survival analysis for the prognostic relationship of Slug expression in HNSCC via the Kaplan-Meier test, we found that patients with high Slug expression had a significantly shorter overall survival rate than patients with low Slug expression ( $\mathrm{P}<0.05$ ) (Fig. 6C). Taken together, these results demonstrate that Slug overexpression is associated with metastasis to lymph nodes and poor survival rate in patients with HNSCC.

\section{Discussion}

In this study, we found that TNF- $\alpha$-induced Slug stabilization plays a critical role in inflammation-induced EMT and cancer cell migration in HNSCC. NF- $\kappa B$ activity is essential for TNF- $\alpha$-induced Slug stabilization. Furthermore, TNF- $\alpha$ induces Slug stabilization by inhibiting its ubiquitination in HNSCC cells. Thus, the TNF- $\alpha-N F-\kappa B-S l u g$ axis represents a potential therapeutic target for inflammation-related metastasis in HNSCC (Fig. 7).

Slug plays an essential role in development [32] and EMT-associated cancer metastasis [33-35]. Mechanistically, Slug binds to cis-elements in the promoter of a number of target genes (e.g., E-cadherin) via its C-terminal "zinc finger" domain and represses gene expression by recruiting chromatin-modifying proteins via its N-terminal "SNAG" domain. Previous studies showed that many factors, such as TGF- $\beta 1$, CD271, CCL18, and the autocrine factor epiregulin, could contribute to the increased expression of Slug in HNSCC cells [36-39]. Although increased Slug expression has been linked to altered transcriptional programs that confer tumor-initiating and invasive capabilities, resistance to apoptosis, and therapeutic failure [40-44], the molecular basis for Slug stabilization in cancer has remained unclear. Here, we explored the mechanism by which the pro-inflammation factor TNF- $\alpha$ acts as a critical factor for Slug protein stabilization. Chronic inflammation is closely correlated to carcinogenesis and metastasis, and TNF- $\alpha$ acts as a major pro-inflammatory cytokine $[21,45$, 46]. TNF- $\alpha$ was originally identified for its ability to induce rapid necrosis in experimental cancers [21]. The persistent expression of TNF- $\alpha$ in the tumor microenvironment is an important feature of many malignant tumors, which is often associated with poor prognosis $[23,24]$. The tumor-promoting effects of TNF- $\alpha$ are facilitated through the enhancement KARGER 
of cancer cell proliferation and survival, angiogenesis, and the formation of an invasive phenotype through various oncogenic pathways. In addition, TNF- $\alpha$ has also been reported to enhance cancer migration and invasion through EMT by stabilizing Snail protein in breast cancer [47]. In this study, we found that Slug was required for TNF- $\alpha$-mediated EMT and metastatic features in HNSCC. Our study provides a mechanistic link between NF$\kappa \mathrm{B}$ activation and Slug overexpression in metastatic HNSCC cells.

Snail and Slug are both members of the Snail family, have a critical role in EMT,

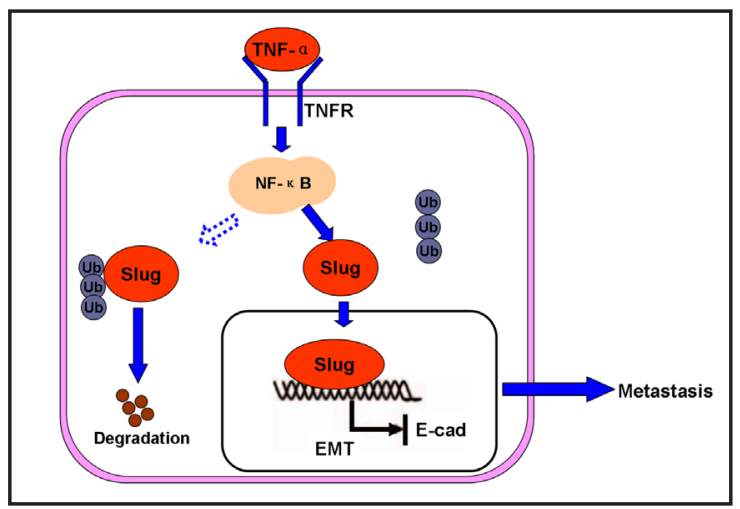

Fig. 7. Proposed model to illustrate the stabilization of Slug by TNF- $\alpha$ leading to EMT and metastasis. and encode transcriptional repressors for the E-cadherin promoter $[8,48,49]$. Upregulated Snail and Slug are associated with aggressiveness, chemotherapy resistance, and poor survival in many cancers [50-52]. A previous study showed that the inflammation-triggered migration, invasion, and metastasis of tumor cells are mediated through NF-KB-induced Snail stabilization in breast cancer. Furthermore, TNF- $\alpha$-mediated Snail stabilization occurs through the induction of CSN2, which blocks the phosphorylation and ubiquitylation of Snail by disrupting its binding to GSK-3 $\beta$ and $\beta$-Trcp, resulting in Snail stabilization in a non-phosphorylated and nonubiquitylated state [47]. In the present study, we showed that TNF- $\alpha$ induced EMT in CAL27 and HN13 cells, while the knockdown of Slug in these cells reversed the EMT phenotype and aggressiveness induced by TNF- $\alpha$. This suggests that Slug plays a major role in mediating TNF- $\alpha$-induced EMT in HNSCC cells. Thus, Slug and Snail, members of the same protein family, may play the same role in different tissues. However, the detailed regulatory mechanisms for these two molecules in different tissues remain to be investigated. Slug reportedly undergoes acetylation-dependent protein degradation, and the deacetylase SIRT2 was identified as a key mediator of this posttranslational mechanism [53]. These findings are in agreement with the notion that Slug is a labile protein that is subjected to delicate regulation by multiple signaling pathways to control its ubiquitylation and degradation. However, whether acetylation is involved in TNF- $\alpha$-mediated Slug protein stabilization still requires further study.

Clinically, lymph node metastasis is considered one of the most important adverse prognostic factors for HNSCC $[54,55]$. The 5-year survival rate for patients with HNSCC at an early stage with a localized site is greater than $80 \%$, but this decreases to $40 \%$ when the disease has spread to the neck nodes [56]. A recent study showed that chronic inflammation is closely correlated with cancer and metastasis through inflammatory cytokines such as TNF- $\alpha$ [57]. However, the mechanism underlying the correlation between inflammation and lymph node metastasis in HNSCC is still unclear. Here, we showed that the overexpression of Slug correlated with lymph node metastasis and predicted poor prognosis in patients with HNSCC. Moreover, Slug was required for TNF- $\alpha$-mediated cancer cell migration and induction of the EMT program. Thus, targeting the TNF- $\alpha$-NF- $\kappa B-S l u g$ axis represents a novel therapeutic strategy for metastatic HNSCC with chronic inflammation.

\section{Acknowledgements}

This work was supported by Shanghai Summit \& Plateau Disciplines, by grant of National Nature Science Foundation of China 81472516 (to JZH), 81572759 (to JD), 81620108022 (to JD), by Shanghai Natural Science Foundation of China 17ZR1416300 (to YW), and by grants of Shanghai Municipal Planning Commission Clinical Center Project.

\section{KARGER}




\section{Cellular Physiology Cell Physiol Biochem 2018;47:567-578 \begin{tabular}{l|l} 
and Biochemistry Published online: $\mathrm{xxx}, 2018$ & $\begin{array}{l}\text { ( ) 2018 The Author(s). Published by S. Karger AG, Basel } \\
\text { www.karger.com/cpb }\end{array}$
\end{tabular}}

Liu et al.: TNF- $\alpha$ Stabilizes Slug via NF-KB in HNSCC

Our study was approved by the ethical committee of the Ninth People's Hospital of Shanghai, China.

\section{Disclosure Statement}

The authors declare that they have no competing interests.

\section{References}

1 Pantel K, Brakenhoff RH: Dissecting the metastatic cascade. Nat Rev Cancer 2004;4:448-456.

$\checkmark 2$ Wu Y, Zhou BP: New insights of epithelial-mesenchymal transition in cancer metastasis. Acta Biochim Biophys Sin 2008;40:643-650.

-3 Wu K, Shen B, Jiang F, Xia L, Fan T, Qin M, Yang L, Guo J, Li Y, Zhu M, Du J, Liu Y: Trpp2 enhances metastasis by regulating epithelial-mesenchymal transition in laryngeal squamous cell carcinoma. Cell Physiol Biochem 2016;39:2203-2215.

-4 Hung TW, Tsai JP, Lin SH, Lee CH, Hsieh YH, Chang HR: Pentraxin 3 activates jnk signaling and regulates the epithelial-to-mesenchymal transition in renal fibrosis. Cell Physiol Biochem 2016;40:1029-1038.

5 Kang Y, Massague J: Epithelial-mesenchymal transitions: Twist in development and metastasis. Cell 2004;118:277-279.

6 Thiery JP, Morgan M: Breast cancer progression with a twist. Nat Med 2004;10:777-778.

7 Yang J, Mani SA, Donaher JL, Ramaswamy S, Itzykson RA, Come C, Savagner P, Gitelman I, Richardson A, Weinberg RA: Twist, a master regulator of morphogenesis, plays an essential role in tumor metastasis. Cell 2004;117:927-939.

-8 Bolos V, Peinado H, Perez-Moreno MA, Fraga MF, Esteller M, Cano A: The transcription factor slug represses e-cadherin expression and induces epithelial to mesenchymal transitions: A comparison with snail and e47 repressors. J Cell Sci 2003;116:499-511.

-9 Comijn J, Berx G, Vermassen P, Verschueren K, van Grunsven L, Bruyneel E, Mareel M, Huylebroeck D, van Roy F: The two-handed e box binding zinc finger protein sip1 downregulates e-cadherin and induces invasion. Mol Cell 2001;7:1267-1278.

-10 Elloul S, Elstrand MB, Nesland JM, Trope CG, Kvalheim G, Goldberg I, Reich R, Davidson B: Snail, slug, and smad-interacting protein 1 as novel parameters of disease aggressiveness in metastatic ovarian and breast carcinoma. Cancer 2005;103:1631-1643.

11 Rosivatz E, Becker I, Specht K, Fricke E, Luber B, Busch R, Hofler H, Becker KF: Differential expression of the epithelial-mesenchymal transition regulators snail, sip1, and twist in gastric cancer. Am J Pathol 2002;161:1881-1891.

-12 Vandewalle C, Comijn J, De Craene B, Vermassen P, Bruyneel E, Andersen H, Tulchinsky E, Van Roy F, Berx G: Sip1/zeb2 induces emt by repressing genes of different epithelial cell-cell junctions. Nucleic Acids Res 2005;33:6566-6578.

13 Polyak K, Weinberg RA: Transitions between epithelial and mesenchymal states: Acquisition of malignant and stem cell traits. Nat Rev Cancer 2009;9:265-273.

14 Yang J, Weinberg RA: Epithelial-mesenchymal transition: At the crossroads of development and tumor metastasis. Dev Cell 2008;14:818-829.

15 Liu T, Zhang X, Shang M, Zhang Y, Xia B, Niu M, Liu Y, Pang D: Dysregulated expression of slug, vimentin, and e-cadherin correlates with poor clinical outcome in patients with basal-like breast cancer. J Surg Oncol 2013;107:188-194.

16 Katafiasz D, Smith LM, Wahl JK, 3rd: Slug (snai2) expression in oral scc cells results in altered cell-cell adhesion and increased motility. Cell Adh Migr 2011;5:315-322.

17 Coussens LM, Werb Z: Inflammation and cancer. Nature 2002;420:860-867.

18 van Kempen LC, Ruiter DJ, van Muijen GN, Coussens LM: The tumor microenvironment: A critical determinant of neoplastic evolution. Eur J Cell Biol 2003;82:539-548.

19 Mantovani A, Allavena P, Sica A, Balkwill F: Cancer-related inflammation. Nature 2008;454:436-444.

20 Mantovani A: Cancer: Inflaming metastasis. Nature 2009;457:36-37. 


\section{Cellular Physiology Cell Physiol Biochem 2018;47:567-578

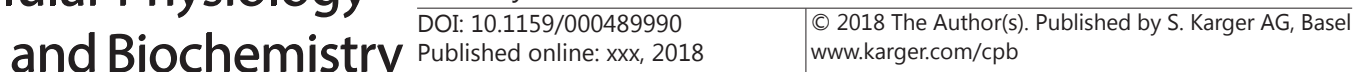

Liu et al.: TNF- $\alpha$ Stabilizes Slug via NF-KB in HNSCC

21 Balkwill F: Tumour necrosis factor and cancer. Nat Rev Cancer 2009;9:361-371.

22 Sethi G, Sung B, Aggarwal BB: Tnf: A master switch for inflammation to cancer. Front Biosci 2008;13:50945107.

23 Krishnan R, Thayalan DK, Padmanaban R, Ramadas R, Annasamy RK, Anandan N: Association of serum and salivary tumor necrosis factor-alpha with histological grading in oral cancer and its role in differentiating premalignant and malignant oral disease. Asian Pac J Cancer Prev 2014;15:7141-7148.

24 Yapijakis C, Serefoglou Z, Vylliotis A, Nkenke E, Derka S, Vassiliou S, Avgoustidis D, Neukam FW, Patsouris E, Vairaktaris E: Association of polymorphisms in tumor necrosis factor alpha and beta genes with increased risk for oral cancer. Anticancer Res 2009;29:2379-2386.

-25 Zhong S, Yin H, Liao Y, Yao F, Li Q Zhang J, Jiao H, Zhao Y, Xu D, Liu S, Song H, Gao Y, Liu J, Ma L, Pang Z, Yang R, Ding C, Sun B, Lin X, Ye X, Guo W, Han B, Zhou BP, Chin YE, Deng J: Lung tumor suppressor gprc5a binds egfr and restrains its effector signaling. Cancer Res 2015;75:1801-1814.

26 Chen D, Liu G, Xu N, You X, Zhou H, Zhao X, Liu Q: Knockdown of ark5 expression suppresses invasion and metastasis of gastric cancer. Cell Physiol Biochem 2017;42:1025-1036.

27 Zhu Y, Gu YX, Mo JJ, Shi JY, Qiao SC, Lai HC: N-acetyl cysteine protects human oral keratinocytes from bisgma-induced apoptosis and cell cycle arrest by inhibiting reactive oxygen species-mediated mitochondrial dysfunction and the pi3k/akt pathway. Toxicol In vitro 2015;29:2089-2101.

-28 Ying Y, Qingwu L, Mingming X, Zhenju S, Chaoyang T, Zhengang T: Emodin: One main ingredient of shufeng jiedu capsule reverses chemoresistance of lung cancer cells through inhibition of emt. Cell Physiol Biochem 2017;42:1063-1072.

29 Liu S, Liu L, Ye W, Ye D, Wang T, Guo W, Liao Y, Xu D, Song H, Zhang L, Zhu H, Deng J, Zhang Z: High vimentin expression associated with lymph node metastasis and predicated a poor prognosis in oral squamous cell carcinoma. Sci Rep 2016;6:38834.

30 Li H, Yuan X, Yan D, Li D, Guan F, Dong Y, Wang H, Liu X, Yang B: Long non-coding rna malat1 decreases the sensitivity of resistant glioblastoma cell lines to temozolomide. Cell Physiol Biochem 2017;42:1192-1201.

-31 Liu S, Shi L, Yang X, Ye D, Wang T, Dong C, Guo W, Liao Y, Song H, Xu D, Hu J, Zhang Z, Deng J: Nuclear survivin promoted by acetylation is associated with the aggressive phenotype of oral squamous cell carcinoma. Cell cycle (Georgetown, Tex) 2017;16:894-902.

-32 Barrallo-Gimeno A, Nieto MA: The snail genes as inducers of cell movement and survival: Implications in development and cancer. Development 2005;132:3151-3161.

-33 Batlle E, Sancho E, Franci C, Dominguez D, Monfar M, Baulida J, Garcia De Herreros A: The transcription factor snail is a repressor of e-cadherin gene expression in epithelial tumour cells. Nat Cell Biol 2000;2:8489.

-34 Cano A, Perez-Moreno MA, Rodrigo I, Locascio A, Blanco MJ, del Barrio MG, Portillo F, Nieto MA: The transcription factor snail controls epithelial-mesenchymal transitions by repressing e-cadherin expression. Nat Cell Biol 2000;2:76-83.

-35 Peinado H, Olmeda D, Cano A: Snail, zeb and bhlh factors in tumour progression: An alliance against the epithelial phenotype? Nat Rev Cancer 2007;7:415-428.

-36 Liu S, Ye D, Xu D, Liao Y, Zhang L, Liu L, Yu W, Wang Y, He Y, Hu J, Guo W, Wang T, Sun B, Song H, Yin H, Liu J, Wu Y, Zhu H, Zhou BP, Deng J, Zhang Z: Autocrine epiregulin activates egfr pathway for lung metastasis via emt in salivary adenoid cystic carcinoma. Oncotarget 2016;7:25251-25263.

-37 Hino M, Kamo M, Saito D, Kyakumoto S, Shibata T, Mizuki H, Ishisaki A: Transforming growth factor-beta1 induces invasion ability of hsc-4 human oral squamous cell carcinoma cells through the slug/wnt-5b/ mmp-10 signalling axis. J Biochem 2016;159:631-640.

-38 Wang H, Liang X, Li M, Tao X, Tai S, Fan Z, Wang Z, Cheng B, Xia J: Chemokine (cc motif) ligand 18 upregulates slug expression to promote stem-cell like features by activating the mammalian target of rapamycin pathway in oral squamous cell carcinoma. Cancer Sci 2017;108:1584-1593.

-39 Chung MK, Jung YH, Lee JK, Cho SY, Murillo-Sauca O, Uppaluri R, Shin JH, Sunwoo JB: Cd271 confers an invasive and metastatic phenotype of head and neck squamous cell carcinoma through the upregulation of slug. Clin Cancer Res 2018;24:674-683.

40 Chang TH, Tsai MF, Su KY, Wu SG, Huang CP, Yu SL, Yu YL, Lan CC, Yang CH, Lin SB, Wu CP, Shih JY, Yang PC: Slug confers resistance to the epidermal growth factor receptor tyrosine kinase inhibitor. Am J Respir Crit Care Med 2011;183:1071-1079. 


\section{Cellular Physiology Cell Physiol Biochem 2018;47:567-578 \begin{tabular}{ll|l} 
DOI: 10.1159/000489990 & $\begin{array}{l}\text { O 2018 The Author(s). Published by S. Karger AG, Basel } \\
\text { www.karger.com/cpb }\end{array}$ \\
\hline and Biochemistry Published online: $x x x, 2018$ &
\end{tabular}}

Liu et al.: TNF- $\alpha$ Stabilizes Slug via NF-KB in HNSCC

-41 Guo W, Keckesova Z, Donaher JL, Shibue T, Tischler V, Reinhardt F, Itzkovitz S, Noske A, Zurrer-Hardi U, Bell G, Tam WL, Mani SA, van Oudenaarden A, Weinberg RA: Slug and sox9 cooperatively determine the mammary stem cell state. Cell 2012;148:1015-1028.

42 Kurrey NK, Jalgaonkar SP, Joglekar AV, Ghanate AD, Chaskar PD, Doiphode RY, Bapat SA: Snail and slug mediate radioresistance and chemoresistance by antagonizing p53-mediated apoptosis and acquiring a stem-like phenotype in ovarian cancer cells. StemCells 2009;27:2059-2068.

-43 Wang SP, Wang WL, Chang YL, Wu CT, Chao YC, Kao SH, Yuan A, Lin CW, Yang SC, Chan WK, Li KC, Hong TM, Yang PC: P53 controls cancer cell invasion by inducing the mdm2-mediated degradation of slug. Nat Cell Biol 2009;11:694-704.

-44 Wu WS, Heinrichs S, Xu D, Garrison SP, Zambetti GP, Adams JM, Look AT: Slug antagonizes p53-mediated apoptosis of hematopoietic progenitors by repressing puma. Cell 2005;123:641-653.

45 Wu Y, Zhou BP: Inflammation: A driving force speeds cancer metastasis. Cell cycle 2009;8:3267-3273.

-46 Lin Z, Sun L, Chen W, Liu B, Wang Y, Fan S, Li Y, Li J: Mir-639 regulates transforming growth factor betainduced epithelial-mesenchymal transition in human tongue cancer cells by targeting foxc1. Cancer Sci 2014;105:1288-1298.

47 Wu Y, Deng J, Rychahou PG, Qiu S, Evers BM, Zhou BP: Stabilization of snail by nf-kappab is required for inflammation-induced cell migration and invasion. Cancer cell 2009;15:416-428.

48 Hajra KM, Chen DY, Fearon ER: The slug zinc-finger protein represses e-cadherin in breast cancer. Cancer Res 2002;62:1613-1618.

49 Moreno-Bueno G, Cubillo E, Sarrio D, Peinado H, Rodriguez-Pinilla SM, Villa S, Bolos V, Jorda M, Fabra A, Portillo F, Palacios J, Cano A: Genetic profiling of epithelial cells expressing e-cadherin repressors reveals a distinct role for snail, slug, and e47 factors in epithelial-mesenchymal transition. Cancer Res 2006;66:9543-9556.

-50 De Craene B, Berx G: Regulatory networks defining emt during cancer initiation and progression. Nat Rev Cancer 2013;13:97-110.

51 Shih JY, Yang PC: The emt regulator slug and lung carcinogenesis. Carcinogenesis 2011;32:1299-1304.

52 Merikallio H, T TT, Paakko P, Makitaro R, Kaarteenaho R, Lehtonen S, Salo S, Salo T, Harju T, Soini Y: Slug is associated with poor survival in squamous cell carcinoma of the lung. Int J Clin Exp Pathol 2014;7:58465854.

53 Zhou W, Ni TK, Wronski A, Glass B, Skibinski A, Beck A, Kuperwasser C: The sirt2 deacetylase stabilizes slug to control malignancy of basal-like breast cancer. Cell Rep 2016;17:1302-1317.

54 Leemans CR, Tiwari R, Nauta JJ, van der Waal I, Snow GB: Recurrence at the primary site in head and neck cancer and the significance of neck lymph node metastases as a prognostic factor. Cancer 1994;73:187-190.

55 DiTroia JF: Nodal metastases and prognosis in carcinoma of the oral cavity. Otolaryngol Clin North Am 1972;5:333-342.

56 Grandi C, Alloisio M, Moglia D, Podrecca S, Sala L, Salvatori P, Molinari R: Prognostic significance of lymphatic spread in head and neck carcinomas: Therapeutic implications. Head Neck Surg 1985;8:67-73.

-57 Wu Y, Zhou BP: Tnf-alpha/nf-kappab/snail pathway in cancer cell migration and invasion. Br J Cancer 2010;102:639-644. 